\title{
Managing International Assignments (Expatriates and Inpatriates): Effect of Cultural Diversity
}

\author{
Amal. M. Jawad ${ }^{1}$ \\ ${ }^{1}$ The Business School, Edinburgh Napier University, Edinburgh, UK \\ Correspondence: Amal. M. Jawad, The Business School, Edinburgh Napier University, Edinburgh, UK. E-mail: \\ amal.jawad@napier.ac.uk
}

Received: October 12, 2020

Accepted: November 2, 2020

Online Published: November 6, 2020

doi:10.5539/ijbm.v15n12p78

URL: https://doi.org/10.5539/ijbm.v15n12p78

\begin{abstract}
Research on the management of expatriates and inpatriates' international assignments within MNCs, such as tasks that include issues expatriates and inpatriates face in different environments. This study verified the challenges of managing expatriates and inpatriates within MNCs in an IHRM field. A qualitative semi-structured interview approach was used with 15 participants (professional engineer's senior's, juniors, and management staff, who held international assignments or worked in abroad positions within MNC (organisation A). The study results that expatriates and inpatriates management in cross-culture diversity allowed them to build their career aspirations. The study described cross-cultural career progression for expatriates and inpatriates management.
\end{abstract}

Keywords: multinational companies, cross-culture, expatriates, inpatriates, challenges

\section{Introduction}

Multinational companies in this global economy decade have tried to sustain their business around their units through different regions (Moeller et al., 2010) to get a competitive advantage. MNCs depend on international assignments to run units between the headquarters and their subsidiaries. In the twentieth century, there was increasing relocation of expatriation from headquarters to foreign subsidiaries. Recently, this has declined (Harvey et al., 2000; Harzing et al., 2016). The first reason behind this change is the rising cost of foreign assignments and localization strategies (Kong, 2018), as MNCs increasingly employ expatriate nationals, so-called self-initiated expatriates because they cost less. (Tung, 2016) explained that HCNs are handling top position from emerging markets since those markets are understood as weak in progress. Consequently, a failure to employ the best local talent prevented MNCs from the success of their foreign subsidiary operations and can increase ongoing problems in post-acquisition integration (Kong, 2018). Second, there is a lack of knowledge from expatriates' assignment of the headquarter managers in the foreign markets (Harzing et al., 2016). Therefore, various types of international assignments, such as expatriates, are flattering growing for developing expertise and building competitive advantages in foreign markets (Froese et al, 2016). Different types of assignments function for various purposes in MNCs present various challenges (Collings et al., 2010; Moeller et al., 2016). Another variety of international assignments is moving subsidiary employees to the headquarters, which is identified as inpatriation (Harzing et al., 2016). MNCs utilize inpatriates to transfer a valuable tacit knowledge implanted in subsidiary employees regarding foreign markets (Reiche, 2011).

Recently, MNCs recognised the need to integrate HRM into the company programme (Almond, 2004). National economic development, competitive pressures, the advance of production, and technology methods reinforced MNCs need to bring human resource management into line with the strategy chosen. Since IHRM is complicated globally, the HRM approach in MNCs diverse.

The current study aimed to evaluate managing expatriates and inpatriates processes in MNCs associate in IHRM from the perspective of professional engineers (senior and junior) and management staff. The paper starts with an introduction to the literature on international assignment, HRM, and IHRM influence in managing the workforce in expatriates and inpatriates literature. It is notable to international human resource managers because they control international staff, which involves selecting, training, development, retention, and managing the global workforce assignments to improve their performance. Then the literature review, methodology, data collection, data analysis, findings, and study summary follow. 


\section{Literature Review}

Multinational companies (MNCs) run in emerging markets, and many of those become powerful players in global business. The global work outlines have complicated circumstances and collaborating diverse culture in different countries and is often involved in diverse national cultures and background (Ravlin et al., 2014). To operate globally, the MNCs must reach agreements with other countries, and their operation should be adjusted to the laws of the host country, cultural values, and behavioral norms (Al Ariss, Cascio \& Paauwe, 2014). MNCs must recognize the importance of human resources to gain a competitive advantage and could find these resources in different places in the world (Bryan et al., 2006).

The literature review started with the IHR role in MNCs, managing international assignments. Further, changing demographics and workforce diversity, global workforce recruitment and selection, cross-cultural training, and development for overseas assignments, employee retention, and career outcome.

\subsection{HR Role in Multinational Companies}

IHRM studies try to transfer the context of HRM action to a global scale to support multinational companies (MNCs) managing at that standard (Haak et al., 2017; Al Ariss \& Sidani, 2016). Lately, the fast pace rapidity of internationalization and globalization result in various strategic turns for HRM (Novicevic \& Harvey, 2000). It implies HR's role is distinctly different domestically and globally for traditional international assignments. Researchers are trying to explore human resource strategy and international organisational strategy (Farndale et al., 2010). Researchers argued that the HR role at the international level was ignored in the IHRM. However, the HR role at the global level was mentioned by (Ghoshal \& Bartlett, 1997), who emphasized that the MNCs' accomplishment depends on the recruitment, training, and development of managers. More particularly, (Shaffer et al., 2012) asserted, MNCs faced issues by formulating their strategies with HRM in a global context. Over the past 15 years, the most significant development of HRM focuses on managing the human capital to the success of organisations globally and at the national level (Taique \& Schuler, 2010,2012). The increasing complications lead to growing teams in the global business, instantaneously affecting the management of the organisations globally, nationally, and regionally. Indeed, the scholars and firms replied that the changes are effective in the IHRM field (Mockaitis et al., 2018).

Moreover, the challenge of integrating human capital on a global level affect the company strategy and maintains performance levels through MNCs units. In particular, the researcher noted that global preparation provides MNCs the ability to face the challenge of global talent management, more specifically, rotating international assignments seen for developing global competence in expatriates and inpatriates. Scholars described it at the greater benefits by involving the employees in the rotational international teams' assignments. Therefore, the typical IHRM themes as selection, training, and retention, but Tung (2016) added that compensation and repatriation should be related to the global work mobility context.

\subsection{Managing the International Assignments}

\subsubsection{International Assignments}

Global workforce practices are changing (Collings et al., 2007; Collings \& Isichei, 2018) and multinational companies (MNCs) are practising different types of international assignments (Collings et al., 2012). Therefore, international assignments are seen as a mechanism used by headquarters to manage their subsidiaries, are also used to transfer knowledge where national know-how is lacking. However, these assignments are recognised to play an important role as a method of knowledge transfer between subsidiaries and headquarters (Harzing et al., 2016).

A challenge for top management and senior executive is to locate appropriate strategies for national and organisational culture through the host country (Warhurst, 1997, Aziz Jalloh, 2015). There are many approaches to testing cultural diversity and their influence on IHRM. By developing organisational culture, the firms, can face challenges related to cultural diversity (Hinds et al., 2011). Recently scholars pointed out the emotional abilities involved in managing diverse cultures. Researchers indicated emotional management designs by values of the culture, norms, and beliefs. Therefore, emotional efficiency may be established in handling and practicing through cultures and formalising to environmental needs through international assignments (Froese et al., 2016).

Past research indicated that HR managers' assessment of subsidiary information quite coordinated with the assistance of the rest subsidiary executives (Chang et al., 2012). Globalisation becomes very complicated in developing the world because the organisational strategy at the local level involves designing the approach, as Lo (2014) indicated that by getting a balance between the local and global setting a good direction between the local and global can substitute on managing globalization. IHRM is a key of regionalisation and increase in the human resource role, as stated by Al Ariss and Sidani (2016). IHRM tris to change the context of HRM activities to a 
global level to assist multinational companies (MNCs) to gain competitive advantages at the units. The importance of cross-cultural adjustment in individuals in the pursuit the international assignments, moreover, it is a key role of these two cultural aspects in influencing expatriation.

\subsubsection{Expatriates}

The operation of globalization increased expatriates working abroad. Nowadays, MNCs are looking for various types of employees around the world. (Collings \& Isichei, 2018). Scholars focused on expatriates as global employees who move internationally to HCN for a fixed duration of time (Shaffer et al., 2012). Mainly, expatriates described themselves as an important talent pool within MNCs (Meyer \& Xin, 2018). But lines to managing expatriates of MNCs successfully have not been understood by researchers (Zhu et al., 2018). MNCs and their expatriates lack experience in global operation and expansion (Liu \& Zhou, 2016; Fan et al., 2016). Expatriates consider the most expensive employees for MNCs to hire. Therefore, they cost organisations three to four times that of employees, ordinary salary. This additional expense has forced many MNCs to reduce expatriates' incentives (Warneke, 2011) to control the cost. Lack of success in applying the management from the IHRM result in massive costs effort. Thus, exploring a dynamic (IHRM) approach is important for maintaining and success of MNCs (Change et al., 2012).

Recently, MNCs focused on external foreign direct investment (FDI) from developing economies (Luo, 2016); however, there is little research on how MNCs manage global human resources. Past researchers stated that exploring the international workforce strategies of MNCs is a critical challenge for the future (Wood \& Demirbag, 2014; Wilkinson \& Shah, 2012). The second domain takes an institution-based view and debates that impact from the host country institutions or the top management. Such as emerging economy governments predominant of MNCs (Wang et al., 2014); however, the HCN institutions determine whether MNCs are legitimate or not (Cui \& Jiang, 2012). Further, the emphasis of the institutions came from both the host and home countries on MNCs. Jepperson (1991) argued that institutions are the output of purposive actions. Recognition of the institutional work increasing in academic an important strain of the institutional learning (Voronov \& Weber, 2016; Xing et al., 2018).

Further, used institutional work as a theoretical foundation, this research suggests that international assignees and their tasks could sustain, create, and damage institutions. However, IHRM practices and rules are institutionally restricted and bound to some extent (Jackson \& Horwitz, 2017), which can make the possibilities of the observation on another side. HR managers, go against the IHRM challenges, as set up of the global strategy of companies by considering a diverse environment and different backgrounds. Furthermore, increasing the need for coordinating and integrating international activities from the headquarter organization across the mobility of top expatriates, managers, and high-potential employees. The central strategic control and HR played a key role in the delivery of strategic human resources as managing the mobility of expatriates globally (Collings, 2019). According to (Harzing et al., 2016), expatriates involves for many purposes, such as knowledge transfer, individual development, and an assortment of social control within the corporation.

Looking at knowledge transfers, expatriate managers play a crucial role between the home and host organisation (Chang et al., 2012). Expatriate managers act as teachers to transfer knowledge by contributing knowledge to foreign subsidiaries, but they also helped inpatriates to transfer knowledge back home (Chang et al., 2012; Horak \& Yang, 2016). They argued that expatriate managers could be significant sources due to their ability to transfer implicit and explicit knowledge (Harzing, 2007). Second, within MNCs the headquarters uses expatriate managers to hold social control upon and aid its foreign subsidiaries (Jensen \& Meckling, 1976). One of the critical tasks of expatriates' work is to handle and control the problems in knowledge transfer (Chang, Gong \& Peng, 2012). It means the knowledge transfer is extended by social capital, share values, and increased knowledge of emotional efficiency (Nair et al., 2017). In these means, by connecting the home and host-unit workforce, expatriates assist in managing and developing in and outflowing social capital and accessible transfer knowledge through MNCs subsidiaries (Reiche et al., 2009; Kostova \& Roth, 2003).

Björkman et al. (2006) showed that expatriates' managers draw connection across information and knowledge movement. Hence, the main issues of running business globally are to attract talented employees to cross-cultures, as needs to be focused on cultural diversity. Furthermore, generic challenges for skills expatriates are language and communication noise (Beamond et al., 2016).

\subsubsection{Inpatriates}

Utilizing inpatriates by the organisation is developing strategic awareness and high levels of business expertise between MNCs workforce to maintain a competitive through the globe and facilitate coordination (Harzing et al., 2016). Indeed, the growth of the emerging economies reinforces MNCs plan to the local market experts (Harvey $\&$ Novicevic, 2000). For these reasons, using inpatriate managers are useful for such reasons. 
When opening the branches in a new market, the first challenge facing MNCs is the need to handle unfamiliar culture and economic situations (Johnson et al., 2006). Initially, MNCs often lack experience in a new market and environment (Reiche, 2011). In this regard, domestic employees are fulfilling this gap due to their knowledge of the home country (Vance et al., 2009). But the staffing of HCN cannot close this gap without helping MNCs to apply and use the knowledge through various units (Vance et al., 2009). Further, since knowledge is tacit, embedded in specific employees and culture accustom (Harvey et al., 2002), moving of local, national HCNs to the headquarters implies knowledge transfer (Reiche, 2011). In this line, inpatriation practices help to widespread and expertise further expand on the subsidiaries (Moeller \& Reiche, 2017).

Furthermore, the knowledge transfer results in long-term retention of inpatriates (Reiche et al., 2011). This means that inpatriates are more suitable to transfers of tacit and implicit knowledge compared to expatriates because of their better cultural and contextual awareness and depth-in understanding the information needs (Harzing et al., 2016). The second inpatriation assignments training of HCNs local employees for MNCs strategic goals. Nowadays, international organisations prefer managers who participated in applying the company strategy through various locations and support the subsidiary units (Reiche et al., 2009). This implies, inpatriates are capable of transferring tacit knowledge across MNCs units and well suited for boundary-spanning positions (Reiche, 2011), however, assigning them to the headquarter enables them to be familiarizing with organisational business principles and values (Harvery et al. 1999). In this regard, inpatriates improve strategic adjustment value through MNCs subsidiaries and facilitate knowledge transfer (Moeller \& Reiche, 2017).

Furthermore, inpatriates are motivated, have career growth opportunities, and valuable for knowledge sharing behaviours (Reiche et al., 2009). The third purpose of using the inpatriation assignments concentrates on crosscultural diversity in MNCs (Moeller et al., 2016). MNCs create effective multicultural management teams from the mixing inpatriates with MNCs national country managers (Reiche and Moeller, 2011). Also, MNCs strengthen the links between units by this collaboration with employees' cross-culture countries, which is contributory to developing a quiet global company mindset throughout the organisation (Harvey et al., 2000). Further, inpatriates enable mentoring of talented employees for new inpatriation assignments and also help to recruit new employees (Harvey \& Novicevic, 2000) because they have a high reputation among subsidiary employees that helps in management and communication (Reiche et al., 2009).

\subsection{Global Work}

Global work at the organisational level, refers to the collaboration between the workers across units (Hinds et al., 2011). Thus, a key aspect of global work is how workers manage cross-culture for any organisation. In contrast, career progression is involved for employees. In the past, researchers have explored the job role of employees who practice international expatriates and inpatriates assignments (Shaffer et al., 2012). Researchers studies divided it into the two stands. The first view is concerned with the nature of global work in MNCs and outcomes (Caligiuri, 2014). Which is covering WLB (Shaffer et al., 2016), (SPLIT) includes the developing a structure, process, language, identity, and technology framework of global teams (Neeley, 2015), and HR system that is concerned about global work (Pudelko \& Harzing, 2007). The second stance is concerned about global work arrangements (Shaffer et al., 2012). Studies of global work, within a cross-cultural perspective, are demanding (Baruch et al., 2013). Indeed, the knowledge transferred within the global work of employees transferred from the advanced countries to developing countries (Takeuchi, 2010). Additionally, cultural diversity can ease international growth.

In this regard, lacking known about the influence of institutions, some researchers debate that culture is a segment of the institutional theoretical shape. For example, different lines of institutional theories involved with culture, more precisely, shared values (Holmes et al., 2013). MNCs worked in multiple institutional situations affect employees carry on international assignments and legitimacy issues when employees move to a new location and challenges for transfers of knowledge (Reiche, 2012).

Cultures and people's values differ from country to another. The most known study of cross-cultural dimensions is that of Hofstede (1980), who initially set out cultural dimensions. Such cultural values are thought of as having a strong influence on workplace policies and practices (Hofstede, 1980), including HRM aspects (Tosi \& Greckhamer, 2004). Also, the workforce demographics are changing gradually but significantly (Tarique \& Schuler, 2012), leads to workforce diversity. The population in developed countries is expected to stay stable or shrink in some regions. However, the populations of developing and emerging countries are increasing, and the average ages are decreasing (Strack et al., 2008). Past research indicated that the generation born in the 1980s likes to work far from their home and look for better opportunities to get global experience and career progression (Farndale \& Paauwe, 2007; Faust, 2008). Therefore, HR managers challenges their workforce planning from different generations, particularly referring to Generation X and Generation Y employees (Faust, 2008) to work effectively 
within the global business, further selecting, developing, and retaining that workforce. Under these situations, carrying out $\mathrm{HR}$ practices and policies is challenging for HR professional and practitioners to meet employee needs (Marjorie, 2008). The cross-cultural and cross-border expansion of companies resulted in the emergence of a new class of people, who hold global attitudes, exhibit global behaviours, and have global networks of relations (Day \& Greene, 2008). MNCs facing challenges from extending the global market, increasing workforce mobility among organizations.

For such reasons, MNCs must be sensitive to linguistic differences and diverse cultures (LIoyd \& Hartel, 2016). The main task for HR is managing diverse cultures among groups. Recently, the concept of diverse culture helps in facilitating normalization and reducing employees' difficulty within the new area (Black et al., 1991). Researchers argued that suspicion, uncertain conditions, and lacking in control in one's foreign subsidiary influence post-settlement adjustment for the employees. Research indicates, cultural adjustment is key to success, which covers the retention and the end of the assignment (Bhaskar- Shrinivas et al., 2005). The basis for cultural difference awareness is a crucial instrument to succeed more linguistically for different employees. Thus, it is crucial in helping HR managers in the selection, post-settlement planning, and adjustment of the individual for MNCs. The next section will explore these issues.

\subsection{Recruitment and Selection}

The precise planning for international selection and recruitment results in the right candidate in the right place within the international posts. IHR managers within the MNCs should have a clear international view when they are planning to recruitment, due to the diverse culture between the headquarters and their foreign subsidiaries. These challenges affect recruitment and selection because of the different legislations through countries. Moreover, the complexity of legitimacy in HCN compares to headquarters managers (Bhaskar-Shrinivas et al., 2005). To recruit the right candidate, need to possess particular competencies that characterise globally, such as, crosscultural knowledge, value, and behaviours (Tarique \& Schuler, 2012). Within the globalization work and skill deficits, the international work preparation needs to meet significant organizational goals (Derven, 2016).

According to (Tarique \& Schuler, 2012) the MNCs followed very aggressive strategies to attract talent; reaching the talent pool is a challenge for many organisations. Another challenge for MNCs is competition from the local organisation to attracted talent instead of a multinational organisation (Schmidit, 2011). In this regard, MNCs rely on diversity of development practices and experiences as short-term and long-term assignments, cross-cultural training, participation in global teams (Caligiuri \& Tarique, 2009). The next section explained the development and training programs for MNCs cross-culture.

\subsection{Training and Development}

The efficient management of international assignee (Reiche, 2011) in the global business frame is one of the most challenging tasks for international HR managers. Merged, fierce, and innovation-driven cross-cultural training markets distinguish today's business environment (Moeller et al., 2010).

IHR managers need to plan the training and development of international assignees for global context-hence crosscultural training and development programs (Mezias \& Scandura, 2005). However, employees who are assigned international responsibilities should also adopt a global mindset, as it is the joint responsibility of IHR managers and local employees to share mutual benefits in the global training and development context (Lazarova \& Caligiuri, 2001). Cross-cultural training of international assignees is critical because of the direct and indirect costs to companies in cases of failure (Hocking et al., 2007). Direct costs include the expense of relocating and returning the assignee, compensation packages, and return-related administrative expenses. Indirect costs include potential relational damages with employees, customers, suppliers, and the organisational community. Hence, IHR managers should identify and select employees who are likely to perform effectively in new cultural contexts; who have learning orientation; who have flexible and global mindsets; and who are very culturally intelligent (Harvey et al., 2006). It means they should go beyond merely offering basic cultural orientation, environmental briefings, and language training. The next section explains employee retention.

\subsection{Employee Retention}

Employee retention has been a major issue for many companies worldwide (Barnett, 1995). MNCs aim to employ exceptional people who add value and help the organisation create a culture that cannot be copied (Jackson \& Schuler, 2003). The retention of qualified employees increased among organisations (Tymon, Stump \& Doh, 2010), practitioners, and academics (Scullion et al., 2007). As McKinsey and Company consultants highlighted, there is 'a war for talent' mainly in recruitment for multinational firms, where leaders have a key role in the success of the company (Chambers et al., 1998). 
Nowadays, MNCs adopt a pluralist approach to international staffing decisions between the headquarters and subsidiaries (Bartlett \& Ghoshal, 1998; Novicevic \& Harvey, 2001). This helps individuals with their career commitment and long-term membership in the organisation (Reiche et al., 2009). Employees who are happy with their work environment have fewer reasons to quit their jobs; so, managers should prevent employee turnover by focusing on their employees' job satisfaction, motivation, remuneration, and training and development opportunities. However, MNCs also lose staff when a spouse or partner leaves their job to accept such an offer. Therefore, organisations must recruit employees who can fit with the organisational culture because they are likely to stay longer in the company. The retention of high-caliber employees remains a key issue among HR departments in both local and multinational firms. Local employees' retention is important because they contribute to knowledge, social networks (Novicevic \& Harvey, 2001).

Nationalisation is one of the retention strategies that dictate aspects of employment practices in both the public and private sectors. Encouraging and supporting the employment of local people involves the mobility of nationals in MNCs on a short or long assignment basis leads to a decrease in the share of foreign expatriates across localisation strategy. It fosters international assignments for the local workforce (Harvey et al., 2000). MNCs achieve greater employee retention by adjusting generalizable practices from the home country to create contextspecific practices that are flexible across different hosts and environments show strategies.

\subsection{Career Progression}

Inpatriation assignments to the headquarters demonstrate a career progression to subsidiary managers that is better than other assignments in MNCs (Reiche, 2017). Further, career growth can be precisely for those managers who communicated to headquarters looking at decision-making (Sarabi et al., 2017). Also, Reiche et al. (2011) showed empirical evidence that inpatriates' involvement in the home country produced career aspiration followed by retention. MNCs need managers with headquarter experience and moving between units (Reiche et al., 2009). However, the inpatriates face difficulties in adapting to the headquarter culture, in the absence of support from IHR when they have started their assignment (Maley \& Moeller, 2018).

The researcher recommends supporting and nurturing the inpatriate engagement, while emphasising the communication between the team leader and top management to assist the progress of the assignment. This can take over the critical factors that inpatriates face during the assignment (Maley and Moeller, 2018). However, expatriates through the international assignment can develop international competence (Shaffer et al., 2006) because of individuals rotational between global team assignments.

\section{Methodology}

\subsection{Research Design}

The case study strategy was adopted for the current study since it is a research strategy concerned with a focus in a single context (Eisenhardt, 1989). Research cultural difference within the global workforce needs top management power for such tasks. Expatriates and inpatriates management maintenance with global competitive needs careful planning. For a described fact, to addressing cultural diversity management, the research uses qualitative and inductive approach design. The data was conducted from the 15 employees who practice international assignments within MNCs. The analysis of the data used the content method; the sample was drawn from a single subsidiary of a multinational company, representing the industry oil and gas multinational company case study (organisation A). The contributors met the following criteria, as the senior position, junior position of the professional engineers, and middle management. Table, I profile of the interviewees.

Table 1. Interviewees profiles

\begin{tabular}{llll}
\hline Number of participants & No. of participants/yeas of assignment & Time on assignment & Position level \\
\hline & 5 & $3-4$ years & Senior position \\
& 3 & $4-5$ years & Senior position \\
2 & $2-1$ year & Middle manager \\
2 & $1-4$ years & Junior managers \\
& 3 & less 1 year & Middle Managers \\
\hline
\end{tabular}

\subsection{Data Collection}

In a qualitative study the individuals express their opinion and view and explain how things mean to them (Becker, 1970). Therefore, content analysis was used to process to reach our target of understanding how to manage 
expatriates and inpatriates across-culture with association with IHRM. Likewise, a semi-structured interview was conducted from ten professional engineers and five management staff in collecting the data. Three questions driven from the literature related to managing inpatriates and expatriates cross-culture was used to get the data from the perspective of the engineers and management staff. Thus, the questions covered, What do you think about the HR role in managing the international assignments cross-culture? What are the challenges in managing the international assignments cross-culture? How do you build your career during the international assignments within MNCs? Additionally, the interviewers got in-depth to gain further comprehension by asking probing questions. The interviews were 50-60 minutes, recorded, and transcribed, and then analyzed with the content method - all the data coding to sub-codes related to managing expatriates.

\section{Findings}

Managing inpatriates and expatriates within multinational companies are critical, especially in cross-culture. The study found three themes, (HR role, challenges facing MNCs in the subsidiary, and career development)

\subsection{HR Role}

HR role within the subsidiary, identify by the professional engineers: "The HR role, you can say it has impact or it on the organization overall when they select when they offer salaries and all that stuff."

The quote indicates that HR dealing with employees from different cultures in the subsidiary, emphasis the provision of individualisism and prepared the attractive compensation packages in the cross-cultural context (Mezias \& Scandura, 2005). As a senior mobility manager said:

What those people did, they're review the compensation for the whole employee every three months. So, it's every quarter, they're reviewing the compensation. So, we have an employee in the (x country). He is already start in January 2018, 2019. After three months, we will check housing situation, the market there. For example, the people are coming here to (x country), so we get the oil crisis. Everything is gone up, the petrol and everything ... we check again.

The statement was confirmed from a senior expert engineer:

Here I am an expat on assignment, and so we get some benefits. School is paid for my children. I find that very good. If I were back home and working there, the school would be regular government school, but here is paid ...

Also, HR accountability is to illustrate the host country policies and rules for expatriates, as stated by a middle manager:

But you know when I spoke about those, we also come in here to (x country) as expert. By the way, we have the people in development, same as (x country) here. We have different examples. But the .... They have to follow the regulations, responsibility in the host country. So, like the holiday, locations, all the role, the timing, the working hours, the days of work in the week, so they have to follow...

The quote points out during that the cross-cultural adjustment phase, the international assignee is expected to develop an integrative and flexible understanding of the host-country context. Local values, norms, expectations, and behaviours accepted in an open-minded manner, and the learning experience triggers new ways of thinking in an unfamiliar cultural context.

But there is a doubt about the human resource department at $\mathrm{HCN}$ has not provided the necessary need for the relocation. As stated by a senior engineer:

I joined (organisation A), within six months they were moving me out to the Caribbean on assignment. Then three years in the Caribbean, I came here. So, it is about providing the opportunities to work on new things and improve my career. But key to that is, and this is where I think HR really falls down, is providing the necessary support for those moves. So, for instance, I moved here with my wife and young children, and it wasn't terribly well organized. It wasn't competent in delivery...

The participant revealed that the HR department within the subsidiary unit did not assign employees full integration during and after arrival in the host country. Therefore, HR managers should encourage the assignee and offer crosscultural socialisation that addresses more than the assignee's technical abilities. As stated by a middle manager engineer: "And that means that the HR system, there is a lack of an actual HR system within the (organisation A)...regarding the operation and so ..."

The quote shows there is a lacking within the HR system at the subsidiary in MNC (organisation A); the management and administration are lacking to create the level of efficiency that meets the organisation's aims. Furthermore, the HR department is driven by local legislation rather than MNCs' policy. As the senior engineer 
stated:

The HR itself, it's kind of mystery across the (organisation A). I work in five countries, different HR system ... It's varied from country to country. HR is more driven by the local instruction, you can say, and because the marketing on ... is much more toward the organization. The HR is biased by this organization rather than dealing with all the (organisation A)... That's also affected the selection. In general,...

The participant emphasised that the local HR must follow the rules and policies that were thought of by the local government, which might not align with the objective of MNCs. Overall, the HR role should be concerned with attractive compensation package cross-culture context in the subsidiary and support efforts to home-country managers from supervisors, colleagues, and individualised efforts, mindsets, behaviours, and attitudes of employees. It is the cross-cultural context that shapes the international assignee's performance successfully. However, there is a lack in the HR system in the subsidiary unit regarding providing the appropriate training programme which effected the employees' performance.

\subsection{Challenges}

There are several challenges pointed out from the interviewees. One of the most challenge mentions by the participants how to realise the local legislation and culture. As the senior engineer said: "HR national managers' interests don 't support of MNCs goal....since of different legislation..."

The quote illustrates that expatriates suffer from the national legislation of the government to nationalization of the domestic with MNCs in their country. However, expatriates familiar with organisational culture of the headquarters tend to meet challenges during an adjustment to the host country context. As the senior engineer said: "The pre-departure training programs critical for inpatriates... because they need to know about precise knowledge about the country and corporate culture..."

The interview indicates that familiarization across-culture one of the issues facing expatriates. Pre-departure training and development programs should predominantly be concerned with two key areas, such as enhancing cultural awareness and decreasing the level of ethnocentrism. As mentioned in the literature review, the training programs should offer language training, culture orientation, and environmental briefings. Expatriates cannot adapt to the host country culture for an extended period. As mentioned by one of a senior manager:

"Here we face very different culture from back home, it's difficult for our family to adapt to system, in terms of language, weather, the school, but simultaneously we have a good incentive ..."

A raising issue during the assignment was mention by a senior manager:

I've been an expat for a little while now, we kind of just want them to be able to deliver what's promises of them in the least dramatic fashion, the least fussy fashion, if I'm honest. And that's all we really need. We need the honesty, upfront conversations and delivery of what's promised. And then I mean, thereafter we've got obviously the ... There's a lot of ... Does this include the training programs ....

The above quote indicates that expatriates mention the honesty and transparency matter when dealing with expatriates from different cultures. Such as the training and development programs that will meet the unique needs of expatriates. HR managers need to plan for international assignees for a global context - hence cross-cultural programs (Mezias \& Scandura, 2005). Further, the responsibility of HR managers and focal employees is to share mutual benefits in the global training and development context (Lazarova \& Caligiuri, 2001). However, there is a shortage of skill with subsidiaries which emphasis expatriates need. As the senior engineers stated: "We have deficit of talent, the employees here very low skills, they need a lot of training, and development programme..."

The quote points out the subsidiary unit has a shortage of skilled employees. MNCs provided the appropriate training programme for the right candidate after the selection to improve their competencies to the international standard and facing the difficulties of the shortage skills from recruiting domestic employees. However, the local, national employees are very short in skills and knowledge, which will be a big challenge for MNCs. One of the biggest challenges facing MNCs is recruiting the citizens rather than closing the gap from other parts of the world. Another important challenge facing expatriates in MNCs is the development process a cross-cultural needed in most international jobs. As stated by a junior engineer: "We need to develop the required competencies for the local talent..."

An important of the competency development process is the skills and knowledge needed in international and domestic jobs. However, inpatriates' employees sent to headquarters faced difficulties adjusting to staff and culture. As mention by a junior engineer: "me and my family faced consequences of different culture.... because we are unfamiliar to cultural domain at the $H Q . . . "$ 
The interview indicated that the issue with the cross-culture facing inpatriates in the headquarter country. The IHR professionals face stressful encounters with inpatriates and their families to engage with the host country system. Moreover, the cultural differentiation activities are an important task for HR in its operations to make sure that inpatriates are adapting to cultural diversity where they are assigned. The mission needs strong personalities who can change various perceptions and views of the international assignee to their back home. Managing the task is challenging for MNCs, but HR management strategy incorporates such components to efficiency to deliver the issues around cross-culture. Another challenge for inpatriates perceived upon the relocation to the headquarter was indicated by a senior manager: "We faced difficult time, the headquarter employees have perceived us differently in terms of social characteristics, traits etc...."

The above quote points out that the status of inconsistencies happens when the individuals face difficulties and are perceived differently from other members (Lenski, 1954). Furthermore, the inpatriates' category observed lower by the headquarter employees, resulting in conflicted between the new state in the headquarter and the past high state in the subsidiary (Harvey et al., 2000). However, inpatriates provide teamwork as a senior engineer:

I'm in the support, engineering support team working with the operations team on site. So, my daily job is to speak with the team on site and find out if they've been any problems? Is there anything that we need to go and identify? What caused the problems? How do we solve the problem?

The interview indicated that expatriates create effective multicultural management teams on the site from mixing expatriates with host country employees. Further, the participation with teamwork leads to motivating employees, by learning new skills to join the team and meanwhile increase job satisfaction by enhancing the career progression.

To sum up, the interviews highlighted the challenges facing expatriates and inpatriates manifold during their assignment in MNCs and host country company. MNCs worked multiple institutional circumstances simultaneously, and diversity between these institutional environments establish mix-ups employees who approve international assignments, legality issues when workforce transfers to a new location, and challenges for transferring the knowledge (Reiche, 2012). These challenges are intense for employees and their MNCs.

\subsection{Career Progression}

In a concept of career progress, it is most challenging facing MNCs, which is determined by many factors. As stated by a professional engineer: "I think that the cultural adjustment is key to success the employee and progress in their career..."

The above quotes indicated the key facet of adjustment is based on the difference between own cultural and host country location. It is based on beliefs, value systems, legal, and political and economic system (Cao et al., 2012). Further, inpatriates provide opportunities for mentoring by the headquarters, as the words from the junior engineer: "During the international assignment we can gain a lot of knowledge by expert at the HQ....we have great opportunity to progress in our career after we come back home..."

The interviewee shared a junior engineer perception that the mentoring for inpatriates increased the ability of the headquarters to facilitate knowledge transfer (Reiche, 2011). Thus, it is considered a method to ease the run the knowledge through inpatriation. In the same line, MNCs could carry out measures for increasing recognition and absorptive ability at the HQ. The next section will discuss the finding.

\section{Discussion of Findings}

Managing expatriates and inpatriates will play a vital role for HR professionals in MNCs. The key issues with recruitment, selection training, and managing the workforce are dealing with diverse cultures. Further, the legislation, norms, beliefs, employees' value, and pressure from experts with their families to adjust to host countries culture, consider many challenges facing the IHR managers within MNCs.

The finding indicates MNCs should be successful in differentiating cultural activities in its process and must assure expatriates of being pre-preparing to the cross-culture. Moreover, managing expatriates is one of the important tasks to assure that differentiating cultural activities align with MNCs strategy, further, to ensure to the personal ability of HR to handle various perceptions during the international assignments. As stated by (Tung \& Verbeke, 2010), the administration of this process, cross-cultural, is the first step to avoid any consequences. Within the foreign environment, management is a key condition that leads to a significant impact on post-settlement adjustment. (Farh et al., 2010) stated that cultural adjustment is critical to achieving completion of assignments in the organisation.

The selection of the workforce globally covers many challenges. MNCs activities and efficiency of their operations come from the right choice for the required personnel in their units. Further, an appropriate training programme 
after the recruitment process enhance the employee competencies and satisfies their career progression. Additional responsibility to MNCs is to train the recruits employees by sending them to various types of assignments at the headquarters or other foreign subsidiaries, which increase the cost of the training. Recently, MNCs started to hire talented local employees because they are familiar with the local market, local communities, and cultural setting; they do not have a problem with language. Also, their career goal and instated of sending expatriates who will overcome the consequences of adjusting to diverse cultures and many other issues raising with expatriates' families (Sparrow et al., 2011). However, expatriates provide coaching and mentoring that the host country employees need. Thus, the HCN policy obligates the MNCs to recruit the majority of the employees from the local people. Therefore, MNCs should develop GTM systems that help inpatriation assignments for both the sides of the headquarter and subsidiary perspectives and implement IHRM policy around the branches to efficient their business globally.

The cultural distance is specifically critical because inpatriates are adjusting to counter two cultural scopes, the organisational and business culture of the headquarter and new cultural environment, which can be known as dual cultural shock (Moeller \& Harvey, 2010). In this regard, the socialization of inpatriates is challenging, and they have to prepare for that by studying the culture and getting familiar with it (Moeller et al., 2010). To improve the international assignments, MNCs must accurately assess the employees who are an assignee for an international assignment and study their family circumstances, expectations before moving (Harvey et al., 2000). For example, the long-term assignments, MNCs offer the inpatriate's and expatriate's families for giving schooling choices for the children and finding employment for their spouse (Baruch et al., 2016).

The study shows some of the expatriates cannot continue their post because of difficulties familiarizing themselves with foreign subsidisers. Hence, this bearing huge costs for MNCs ((Wu \& Ang, 2011). Recently, MNCs employ interests' people to care and look for expatriates while they are on assignment (Briscoe et al., 2012). The research finds the career experiences and expectations crucial to expatriates. Precisely, when they are clear about the career progress from the international assignment, they probably adjust to the host culture and their job, as well as agree to finish their assignment (Haslberger \& Brewster, 2009). The quantity of knowledge residing in expatriates is stimulating the performance; thus, the authorities powered with such a task should handle it with ultimate diligence and consider it with their strategic when implementing across their subsidiaries. Further, the fair from the rewarding system is a determinant for prominence in MNCs' operations. Expatriates and inpatriates receive additional incentives, such as home allowances, medical insurance, which implies that they are financially well from the home country.

The study finds the knowledge transfer and sharing of former inpatriates have been essential for their career progression. Further, the career prospects are one of the main reasons for the individuals to accept the international assignments (Doherty \& Dickmann, 2012). Also, the study finds participation in teamwork a consequence of different forms of communication networks in organisations. Employees comfortable with their jobs and more committed to organisation compared to those who do not participate, which can affect the retention employees in ensuring that each person knows his or her task. By creating a culture of responsibility, employers improve the morale and productivity of employees and enhance retention in the organisation so reducing turnover costs.

The study finds it important for international assignments to improve engineers' competencies. There are two types of competencies; dynamic and stable (Shaffer et al., 2006). The stable competencies are abilities and reliable characteristics, as personality traits. In contrast, the dynamic competencies indicate to skills and knowledge that are needed through learning and working practices, such as international training and travel, and those competencies according to the situation (Shaffer et al., 2006). For instance, a dynamic competency is 'international travel experience' (Yuan \& Chuang, 2012); within MNCs, having dynamic cross-cultural competencies is a crucial need for both the local and international job (Crossman \& Clark, 2010).

\section{Implications of the Study}

Nowadays, the international Oil and Gas companies competent for professionals talented engineers. It is considered critical to keep them in the organization else to provide them career path clarity. Global organisations must supply career paths to retain and motivate employees by considering the employee's value, desire, and aspiration. International assignments are essential tools for retaining experienced and inpatriates expert engineers to avert corporate insecurity and to reduce the costs (Mignonac \& Herrbach, 2003). Furthermore, as stated by Sarmad et al. (2016) concerning present days' global, competitive, and complex environment, engineers played an important role at every process stage of creating newfangled knowledge and innovation.

Further, retaining expatriates needs an appropriate reward system to accompaniment precise social scarcity. Despite the costly managing expatriates, contributions within MNCs' operations are important because they impact with strategic problems that assist the organizations' to get a competitive advantage. Careful assess expatriates' 
tasks to ensure that strategic targets achieve is the best managing tool.

\section{Conclusion}

Describing diverse cultures leads to the IHRM managers' efficient teamwork. Through examining of the case study from the interviews with professional engineers and team management discovered sufficient proof about the importance of managing inpatriates and expatriates in MNCs with a focus to be culturally different. The data analysis reveals that managing inpatriates and expatriates needs a depth understanding of their various cultures, prepare training and development programme to their missions to be easy to apply. Further, MNCs must allocate rewards and good incentives benefits for people assignee for international assignments. Because of the cost of managing expatriates, the company started to use it inpatriates local employees to reduce the cost and national country employees better prepare for newcomers from abroad (Harvery et al., 1999). However, inpatriates are not recognised as valued knowledge in the headquarters, which makes the completion of inpatriation assignments significantly difficult.

This study used a qualitative method by interviewing the professional engineers and management staff with the case study multinational oil and gas company (organisation A). For future research, the researcher recommends exploring inpatriation and expatriation knowledge transfer that affect expatriates' international assignments and uses different techniques to analyse the data.

\section{Acknowledgements}

I want to share my thanks to the participants of this study who were interested in taking apart and sharing their experiences with me. Their truthful contributions and honesty are the basis of this research, and I am grateful to them for sharing their accounts.

\section{References}

Al Ariss, A., \& Sidani, Y. (2016). Comparative international human resource management: Future research directions. Human Resource Management Review, 26(4), 352-358.

Al Ariss, A., Cascio, W. F., \& Paauwe, J. (2014). Talent management: Current theories and future research directions. Journal of World Business, 49(2), 173-179.

Almond, P., Clark, I., \& Treaskis, O. (2004). HRM in multinationals: A comparative international perspective. In I. Beardwell, L. Holden, \& T. Claydon (Eds.), Human Resource Management: A Contemporary Approach, (4th ed., pp. 587-636).

Aziz Jalloh, A. (2015). Managing expatriates in multinational companies [MNCs]: An international human resource management and cultural diversity perspective. Scholars Journal of Economics, Business and Management. 2(10B), 1060-1071.

Baruch, Y., Altman, Y., \& Tung, R. L. (2016). Career mobility in a global era. Advances in managing expatriation and repatriation. Academy of Management Annals, 10(1), 841-889.

Baruch, Y., Dickmann, M., Altman, Y., \& Bournois, F. (2013). Exploring international work: Types and dimensions of global careers. International Journal of Human Resource Management, 24(12), 2369-2393.

Beamond, M. T., Farndale, E., \& Hartel, C. E. (2016). MNE translation of corporate talent management strategies to subsidiaries in emerging economies. Journal of World Business, 51(4), 499-510.

Becker, H. (1970). Sociological Work - Method and Substance. The Chicago Press.

Bhaskar-Shrinivas, P., Harrison, D. A., Shaffer, M. A., \& Luk, D. M. (2005). Input-based and time-based models of international adjustment: Meta-analytic evidence and theoretical extensions. Academy of Management Journal, 48(2), 257-281.

Bjorkman, I. (2006). International human resource management research and institutional theory. In I. Bjorkman \& G. Stahl (Eds.), Handbook of research into international HRM (2nd ed., pp. 472-489). Edward Elgar.

Black, J. S., Mendenhall, M., \& Oddou, G. (1991). Toward a comprehensive model of international adjustment: An integration of multiple theoretical perspectives, Academy of Management Review, 16(2), 219-317.

Briscoe, D., Schuler, R., \& Tarique, I. (2012). International human resource management (4th ed.). Routledge.

Cao, L., Hirschi, A., \& Deller, J. (2012). Self-initiated expatriates and their career success. Journal of Management Development, 31(2), 159-172.

Chang, Y., Gong, Y., \& Peng, M. W. (2012). Expatriate knowledge transfer, subsidiary absorptive capacity, and subsidiary performance. Academy of Management Journal, 55(4), 927-948. 
Collings, D. G., \& Isichei, M. (2018). The shifting boundaries of global staffing: Integrating global talent management, alternative forms of international assignments and non-employees into the discussion. International Journal of Human Resource Management, 1. http://doi.org/10.1080/09585192.2017.1380064.

Collings, D. G., McDonnell, A., Gunnigle, P., \& Lavelle, J. (2010). Swimming against the tide. Outward staffing flows from multinational subsidiaries. Human Resource Management, 49(4), 575-598.

Collings, D. G., Scullion, H., \& Morley, M. J. (2012). Challenging patterns of global staffing in the multinational enterprise. In G. K., Stahl, M. E. Mendenhall, \& G. R. Oddou (Eds.), Readings and cases in international human resource management and organisational behaviour (5th ed., pp. 198-213). Routledge.

Collings, D., Galigiuri, P. (2019). Global talent management. In D. Collinges \& P. Galigiuri (Eds.), Global talent management (2nd ed., pp. 105-108). Routledge.

Crossman, J. E., \& Clarke, M. (2010). International experience and graduate employability: Stakeholder perceptions on the connection. Higher Education, 59(5), 599-613.

Cui, L., \& Jiang, F. (2012). State ownership effect on firms' FDI ownership decisions under institutional pressure: A study of Chinese outward-investing firms. Journal of International Business Studies, 43(3), 264-284.

Day, N. E., \& Greene, P. G. (2008). A case for sexual orientation diversity in small and large organizations, Human Resource Management, 47(3), 637-654.

Doherty, N. T., \& Dickmann, M. (2012). Measuring the return on investment in international assignments: an action research approach, International Journal of Human Resource Management, 23(16), 3434-3454.

Eisenhardt, K. M. (1989). Building theories from case study research. Academy of Management Review, 14(4), $532-550$

Fan, D., Cui, L., Li, Y., \& Zhu, C. J. (2016). Localized learning by emerging multinational enterprises in developed host countries: A fuzzy-set analysis of Chinese foreign direct investment in Australia. International Business Review, 25(1), 187-203.

Farh, C. I., Bartol, K. M., Shapiro, D. L., \& Shin, J. (2010). Networking abroad; a process model of how expartriates from support ties to facilitate adjustment. Academy of Management Review, 35(3), 434-454.

Farndale, E., \& Paauwe, J. (2007). Uncovering competitive and institutional drivers of HRM practices in multinational corporations. Human Resource Management Journal, 17(4), 355-375.

Farndale, E., Scullion, H., \& Sparrow, P. (2010). The role of the corporate HR function in global talent management. Journal of World Business, 45(2010), 161-168.

Faust, C. (2008). State of the global talent nation report: Organizations struggle to ready workforces to meet growth demands. http://www.softscape.com

Froese, F. J., Kim, K., \& Eng, A. (2016). Language, cultural intelligence, and inpatriate turnover intentions. Leveraging values in multinational corporations through inpatriates. Management International Review, $56(2), 283-301$.

Ghoshal, S., \& Bartlett, C. (1999). The multinational corporation as an inter-organizational network. Academy of Management Review, 15(4), 603-625.

Haak-Saheem, W., Festing, M., \& Darwish, T. K. (2017). International human resource management in the Arab Gulf States - an institutional perspective. International Journal of Human Resource Management, 28(18), 2684-2712.

Harvey, M. G., Novicevic, M. M., \& Kiessling, T. (2002). Development of multiple IQ maps for use in the selection of inpatriate managers. A practical theory. International Journal of Intercultural Relations, 26(5), 493-524.

Harvey, M. G., Ralston, D., \& Napier, N. (2000). International relocation of inpatriate managers. Assessing and facilitating acceptance in the headquarters organization. International Journal of Intercultural Relations, 24(6), 825-846.

Harvey, M. G., Reiche, B. S., \& Moeller, M. (2011). Developing effective global relationships through staffing with inpatriate managers. The role of interpersonal trust. Journal of International Management, 17(2), 150161.

Harvey, M., Novicevic, M. M., \& Speier, C. (2000). Strategic human resource management: The role of inpatriate managers, Human Resource Management Review, 10(2), 153-175. 
Harzing, A. W. (2001). Of bears, bumble- bees and spiders: The role of expatriates in controlling foreign subsidiaries, Journal of World Business, 36(4), 366-379.

Harzing, A. W., Pudelko, M., \& Reiche, B. S. (2016). The bridging role of expatriates and inpatriates in knowledge transfer in multinational corporations. Human Resource Management, 55(4), 679-695.

Haslberger, A., \& Brewster, C. (2009). Capital gains: expatriate adjustment and the psychological contract in international careers. Human Resource Management, 48(3), 379-397.

Hinds, P., Liu, L., \& Lyon, J. (2011). Putting the global in global work: An intercultural lens on the practice of cross-national collaboration. The Academy of Management Annals, 5(1), 135-188.

Hocking, J. B., Brown, M. E., \& Harzing, A. W. (2007). Balancing global and local strategic contexts: Expatriate knowledge transfer, applications and learning within a transnational organization, Human Resource Management, 46(4), 513-533.

Hofstede, G. (1980). Culture's consequences: International differences in work-related values. Sage.

Holmes, R. M., Miller, T., Hitt, M. A., \& Salmador, M. P. (2013). The interrelationships among informal institutions, formal institutions, and inward foreign direct investment. Journal of Management, 39(2), 531566.

Horak, S., \& Yang, I. (2016). Affective networks, informal ties, and the limits of expatriate effectiveness. International Business Review. 25(5). https://doi.org/10.1016/j.ibusrev.2016.01.006

Jackson, T., \& Horwitz, F.M. (2017). Expatriation in Chinese MNEs in Africa: An agenda for research. The International Journal of Human Resource Management, 29(11), 1856-1878.

Jensen, M. C., \& Meckling, W. H. (1976). Theory of the firm: Managerial behavior, agency costs and ownership structure. Journal of Financial Economics, 3(4), 305-360.

Jepperson, R. L. (1991). Institutions, institutional effects, and institutionalism. In W. W. Powell \& P. J. DiMaggio (Eds.), The new Institutionalism in organizational analysis (pp. 143-63). University of Chicago Press.

Johnson, J. P., Lenartowicz, T., \& Apud, S. (2006). Cross-cultural competence in international business: Toward a definition and a model. Journal of International Business Studies, 37(4), 525-43.

Kong, L., Ciabuschi, F., \& Martin, O. M. (2018). Expatriate managers' relationships and reverse knowledge transfer within emerging market MNCs: The mediating role of subsidiary willingness. Journal of Business Research, 93, 216-229.

Kostova, T., \& Roth, K. (2003). Social capital in multinational corporations and a micro-macro model of its formation. Academy of Management Review, 28(2), 297-317.

Lazarova, M., \& Caligiuri, P. (2001). Retaining repatriates: The role of organizational support practices, Journal of World Business, 36(4), 389-401.

LIoyd, S., \& Hartel, C. (2016). Intercultural competencies for culturally diverse work teams. Journal of Managerial Psychology, 25(8), 2010.

Liu, Y., \& Almor, T. (2016). How culture influences the way entrepreneurs deal with uncertainty in interorganizational relationships: The case of returnee versus local entrepreneurs in China. International Business Review, 25(1), 4-14.

Liu, Y., \& Meyer, K. E. (2018). Boundary spanners, HRM practices, and reverse knowledge transfer: The case of Chinese cross-border acquisitions. Journal of World Business, 55(2). https://doi.org/10.1016/j.jwb.2018.07.007

Lo, W. (2014). Think global, think local: The changing landscape of higher education and the role of quality assurance in Singapore. Policy and Society, 33(3), 263-73.

Luo, Y. (2016). Toward a reverse adaptation view in cross-cultural management. Cross Cultural and Strategic Management, 23(1), 29-41.

Maley, J. F., \& Moeller, M. (2018). Inpatriate managers. Are they being effectively utilized as global talent? Thunderbird International Business Review, 60(4), 647-59.

Marjorie, A. (2008). Organizational practices and the post-retirement employment experience of older workers, Human Resource Management Journal, 18(1), 36-53.

Mezias, J. M., \& Scandura, T. A. (2005). A needs-driven approach to expatriate adjustment and career development: 
A multiple mentoring perspective. Journal of International Business Studies, 36, 519-538.

Mignonac, K., \& Herrbach, O. (2003). Managing individual career aspirations and corporate needs: A study of software engineers' willingness to accept intra-organizational mobility opportunities. Journal of Engineering and Technology Management, 20(3), 205-230.

Mockaitis, A. I., Zander, L., \& De Cieri, H. (2018). The benefits of global teams for international organizations: HR implications. The International Journal of Human Resource Management, 18(1), 1-22.

Moeller, M., \& Reiche, B. S. (2017). Inpatriates. A review, synthesis and outlook of two decades of research. In Y. McNulty \& J. Selmer (Eds.), Research Handbook of Expatriates (pp. 218-240). Edward Elgar Publishing.

Moeller, M., Harvey, M., \& Williams, W. (2010). Socialization of inpatriate managers to the headquarters of global organizations: A social learning perspective, Human Resource Development Review, 9(2), 169-193.

Nair, S., Demirbag, M., Mellahi, K., \& Gopalakrishna Pillai, K. (2017). Do parent units benefit from reverse knowledge transfer? British Journal of Management, 29(3), 428-444. https://doi.org/10.1111/14678551.12234

Novicevic, M. M., \& Harvey, M. G. (2001). The emergence of the pluralism construct and the inpatriation process, International Journal of Human Resource Management, 12(3), 333-356.

Pudelko, M., \& Harzing, A. W. (2007). Country-of-origin, localization or dominance effect? An empirical investigation of HRM practices in foreign subsidiaries. Human Resource Management, 46(4), 535-559.

Reiche, B. S. (2011). Knowledge transfer in multinationals: The role of inpatriates' boundary spanning. Human Resource Management, 50(3), 365-389.

Reiche, B. S. (2012). Knowledge benefits of social capital upon repatriation. A longitudinal study of international assignees. Journal of Management Studies, 49(6), 1052-1077.

Reiche, B. S., Harvey, M. G., \& Moeller, M. (2011). Developing effective global relationships through staffing with inpatriate managers. The role of interpersonal trust. Journal of International Management, 17(2), 150161.

Reiche, B. S., Kraimer, M., \& Harzing, A. W. K. (2009). Inpatriates as agents of cross-unit knowledge flows in multinational corporations. In P. Sparrow (Ed.), Handbook of international human resource management: Integrating people, process and context (pp. 151-170). Blackwell.

Sarabi, A., Froese, F. J., \& Hamori, M. (2017). Is inpatriation assignment experience a ticket to the top of a foreign subsidiary? The moderating effect of subsidiary context. Journal of World Business, 52(5), 680-690.

Sarmad, M., Ajmal, M. M, Shamim, M., Saleh, M., \& Malik, A. (2016). Motivation and compensation as predictors of employees' retention: Evidence from public sector O \& G selling organizations. Journal of Behavioural Sciences, 26(2), 2016.

Shaffer, M. A., Harrison, D. A., Gregersen, H., Black, J. S., \& Ferzandi, L. A. (2006). You can take it with you: Individual differences and expatriate effectiveness. Journal of Applied Psychology, 91(1), 109-125.

Shaffer, M. A., Kraimer, M. L., Chen, Y. P., \& Bolino, M. C. (2012). Choices, challenges, and career consequences of global work experiences: A review and future agenda. Journal of Management, 38(4), 1282-1327.

Shaffer, M. A., Reiche, B. S., Dimitrova, M., Lazarova, M., Chen, S., Westman, M., \& Wurtz, O. (2016). Work and family role adjustment of global professionals: Scale development and validation. Journal of International Business Studies, 47(2), 113-139.

Strack, R., Baier, J., \& Fahlander, A. (2008). Managing demographic risk, Harvard Business Review. https://hbr.org/2008/02/managing-demographic-risk

Takeuchi, R. (2010). A critical review of expatriate adjustment research through a multiple stakeholder view: Progress, emerging trends, and prospects. Journal of Management, 36(4), 1040-1064.

Tarique, I., \& Schuler, R. S. (2012). Global talent management literature review. White paper. SHRM Foundation. Retrieved

from https://smlr.rutgers.edu/sites/default/files/documents/faculty_staff_docs/Randall\%20Schuler_GTM\%20SH RM_\%20Report_Final_Oct\%2028\%2C2012_0.pdf

Thite, M., Wilkinson, A., \& Shah, D. (2012). Internationalization and HRM strategies across subsidiaries in multinational corporations from emerging economies - A conceptual framework. Journal of World Business, $47(2), 251-258$. 
Tosi, H. L., \& Greckhamer, T. (2004). Culture and CEO compensation, Organization Science, 15(6), 657-670.

Tung, R. L. (2016). New perspectives on human resource management in a global context. Journal of World Business, 51(1), 142-152.

Vance, C. M., Vaiman, V., \& Andersen, T. (2009). The vital liaison role of host country nationals in MNC knowledge management. Human Resource Management, 48(4), 649-659.

Voronov, M., \& Weber, K. (2016). The heart of institutions: Emotional competence and institutional actorhood. Academy of Management Review, 41(3), 456-478.

Wang, S. L., Luo, Y., \& Lu, X. (2014). Autonomy delegation to foreign subsidiaries: An enabling mechanism for emerging-market multinationals. Journal of International Business Studies, 45, 111-130.

Warhurst, C. (1997). Political economy and the social organization of economic activity: A synthesis of neoinstitutional and labour process analyses. Competition and change, 2, 213-246.

Warneke, D., \& Schneider, M. (2011). Expatriate compensation packages: What do employees prefer? Cross Cultural Management, 18(2), 236-256.

Wilkinson, A., Wood, G., \& Demirbag, M. (2014). People management and emerging market multinationals. Human Resource Management, 53(6), 835-849.

Wu, P. D., \& Ang, S. H. (2011). The impact of expatriate supporting practices and cultural intelligence on crosscultural adjustment and performance of expatriates in Singapore. International Journal of Human Resource Management, 22(13), 2683-2702.

Xing, Y., Liu, Y., \& Cooper, C. (2018). Local government as institutional entrepreneur: Collaborative partnerships in fostering regional entrepreneurship. British Journal of Management, 29(4), 670-690

Yan, Z. J., Zhu, C. J., Fan, D., \& Kalfadellis, P. (2018). An institutional work view toward the internationalization of emerging market firms. Journal of World Business, 53(5), 682-694.

\section{Copyrights}

Copyright for this article is retained by the author (s), with first publication rights granted to the journal.

This is an open-access article distributed under the terms and conditions of the Creative Commons Attribution license (http://creativecommons.org/licenses/by/4.0/). 